\title{
Wildfire effects on hiking and biking demand in New Mexico: a travel cost study
}

\author{
Hayley Hesseln ${ }^{\mathrm{a}, *}$, John B. Loomis ${ }^{\mathrm{b}}$, Armando González-Cabán ${ }^{\mathrm{c}}$, Susan Alexander ${ }^{\mathrm{d}}$ \\ ${ }^{a}$ School of Forestry, University of Montana, Missoula, MT, USA \\ ${ }^{\mathrm{b}}$ Department of Agricultural and Resource Economics, Colorado State University, Fort Collins, CO, USA \\ ${ }^{\mathrm{c}}$ USDA Forest Service, Pacific Southwest Research Station, Forest Fire Laboratory, Riverside, CA, USA \\ ${ }^{\mathrm{d}}$ Corvallis Forestry Sciences Lab, Pacific Northwest Research Station, USDA Forest Service, Corvallis, OR, USA
}

\begin{abstract}
We use a travel cost model to test the effects of wild and prescribed fire on visitation by hikers and mountain bikers in New Mexico. Our results indicate that net benefits for mountain bikers is $\$ 150$ per trip and that they take an average of 6.2 trips per year. Hikers take 2.8 trips per year with individual net benefits per trip of $\$ 130$. Both hikers' and mountain bikers' demand functions react adversely to prescribed burning. Net benefits for both groups fall as areas recover from prescribed burns. Because both visitation and annual recreation benefits decrease to these two types of visitors, this gives rise to multiple use costs associated with prescribed burning. With respect to wildfire, hikers and mountain bikers both exhibit decreased visitation as areas recover from wildfires, however, only hikers indicate an increase in per trip net benefits. Bikers' demand effectively drops to zero. These results differ from previous findings in the literature and have implications for efficient implementation of the National Fire Plan and whether prescribed burning is a cost effective tool for multiple use management of National Forests. Specifically, that fire and recreation managers cannot expect recreation users to react similarly to fire across recreation activities, or different geographic regions. What is cost effective in one region may not be so in another.
\end{abstract}

(C) 2003 Elsevier Ltd. All rights reserved.

Keywords: Recreation demand; Travel cost method; Wildfire; Prescribed fire

\section{Introduction}

Commonly known in the United States as The National Fire Plan (NFP), the "Report to the President in Response to the Wildfires of 2000" (Laverty and Hartzel, 2001), outlines strategies to be undertaken by US agencies to mitigate and fight wildland fire. One of the key aspects of the NFP is the increased use of prescribed fire to reintroduce fire to firedependent ecosystems, and to mitigate the effects of wildfire. Although the use of prescribed fire may be effective from an ecological perspective, the use of prescribed fire may not be socially acceptable or cost effective when social values such as recreation are considered further increasing the debate regarding the desirability of prescribed burning programs.

It is important to incorporate social values in the decision-making process when determining fire management methods, particularly in high-use recreation areas.

\footnotetext{
* Corresponding author. Address: Department of Agricultural Economics, 51 Campus Drive, Saskatoon, SK S7N 5A8, Canada. Tel.: +1-306-966-8407; fax: + 1-306-665-3179.

E-mail address: h.hesseln@usask.ca (H. Hesseln).
}

Whereas prescribed fire treatments may be more cost effective than those of mechanical fuels treatments such as forest thinning, when social costs are included, the reverse may be true. Similarly, prescribed and wildfire may not equally affect users of different recreation activities.

Research investigating social aspects of fire has been done by Englin et al. (1996) and Boxall et al. (1996) who use the travel cost method (TCM) to assess value changes for canoeing in Manitoba, Canada. Loomis et al. (2001) use the TCM to evaluate fire effects on hiking and mountain biking in Colorado. They found that there were differential effects on hiking and mountain biking visitation as a result of different fire ages and the presence of crown fires. Similarly, recreation benefits as measured by consumer surplus for mountain bikers were indirectly affected by crown fire. Earlier research by Vaux et al. (1984) indicated that higher intensity fires negatively affected recreation values, a result also found by the Loomis et al. study. Although seminal research has been conducted by the aforementioned authors, there is a need to expand this work geographically and across alternative recreation activities. Because recreation use varies by activity and location, it is important to assess 
the impacts of fire on value and visitation to determine social effects such as costs and benefits. These costs and benefits will have implications for how management programs are developed and implemented. The existing research raises several questions, including whether hikers and mountain bikers behave similarly across states in response to forest fires. If recreation users' visitation patterns across states are similar, fire managers can predict the economic and social effects of using prescribed fire to mitigate wildfire by drawing upon existing studies. Furthermore, understanding the socioeconomic effects of prescribed fire may suggest that wildland fire is a preferable management alternative. Therefore, this research has implications for the NFP and the resulting social consequences of pursuing a more extensive prescribed burning program. However, if visitors' reactions to fire vary by geographic region, then managers must conduct site specific studies in order to determine socially acceptable fuel treatments for each area.

This study uses the travel cost and contingent behavior methodology as used by Loomis et al. (2001) to determine the effect of fire on hikers and mountain bikers in New Mexico. The survey instrument was identical except for years trips were taken. We also compare these results with the findings of the Colorado study. Results will have implications for the economic and social effects of increasing prescribed burning as proposed by the NFP. Specifically, whether prescribed burning increases or decreases net benefits to recreation users, to what extent, and whether recreation users engaged in different activities react similarly to prescribed burning.

We surveyed recreation users in New Mexico to determine the effects of fire on hikers and mountain bikers. Because the survey was designed to estimate demand for recreation in National Forests based on observed and stated preference, we focused on recreation only in National Forests. We provide a discussion of the methodology used and our hypotheses. Finally, we present our regression results, a summary of our findings, and conclusion.

\section{Econometric methodology}

The number of visits to a recreation site is a function of price (e.g. travel cost and travel time), demographics and site characteristics. Since many site characteristics do not vary within a site, but vary between sites, a multi-site recreation demand function is needed to estimate a coefficient on how visitation changes with site characteristics. There are two general approaches to incorporating site characteristics into recreation demand: (a) varying parameters model (Vaughan and Russell, 1982) and the random utility model framework (Morey, 1982).

When individuals take more than one trip to a site during a season, the continuous trip or interior solution varying parameter model is more appealing than the corner solution random utility model because of the ease by which multiple trips are directly modeled as the dependent variable in the varying parameter model. Incorporating multiple trips into the random utility model involves linking site choice and trip frequency or using a repeated logit model, a more cumbersome modeling process.

Site characteristic variables are included as demand shift variables, and can be interacted with the price slope to allow for different price elasticities and consumer surplus per trip to different sites. Thus the varying parameters travel cost model can account for differences in site quality despite estimating just one set of parameters. In some ways this is similar to the random utility model, which estimates one set of price and quality parameters applicable to multiple sites.

The varying parameter foundation has been repeatedly used in recreation demand modeling since Vaughan and Russell's first application. Recent applications include Loomis et al. (1995), Ward et al. (1996) and Ward and Beal (2000).

Loomis et al. (1999) conducted a travel cost survey in Colorado to test the effects of fire on recreation for hikers and mountain bikers. Similarly, the Colorado data were also used by Englin et al. (2001) to estimate the differences in demand between Colorado and Idaho/Wyoming sites. We use the survey developed by Loomis et al. to evaluate fire effects on recreation users in New Mexico. By employing a count data travel cost model, we can calculate consumer surplus by integrating the area under the demand curve between visitors' current travel costs and the travel cost that would eliminate visitation. We measure actual trips taken, and intended trips based on contingent behavior, as a function of site and fire characteristics, demographics, and travel cost information.

We use a Poisson count data specification of the recreation demand function because the number of trips taken is a non-negative integer. Because we are combining revealed preference and stated preference data, we use the panel data methodology developed by Englin and Cameron (1996). Stated preference data were combined with revealed preference observations to augment the database in terms of fire intensities and fire ages not present in the actual trip data. Trips taken were measured as a function of site characteristics, fire effects, travel cost information and demographics. The general form of the Poisson model is given by Eq. (1)

$f\left(y_{i} \mid x_{i}, \beta\right)=\frac{\mathrm{e}^{-m\left(x_{i}, \beta\right)} m\left(x_{i}, \beta\right)^{y_{i}}}{y_{i} !}$

where $y_{i}$ is trips taken, $m$ is the average value of trips taken, and $\beta$ is a vector of parameters to be estimated. The maximum likelihood estimator of $\beta$ is generated by maximizing the log likelihood function given by Eq. (2).

$l(\beta)=\sum_{i=1}^{N} y_{i} \log m\left(x_{i}, \beta\right)-m\left(x_{i}, \beta\right)-\log \left(y_{i} !\right)$ 
Specific formulation of the model expressed by Eq. (3) shows factors varying across individuals, scenarios and sites

$$
\begin{aligned}
E\left[\text { TRIPS }_{i j}\right]= & \exp \left(\alpha_{0}+\beta_{1}\left(\text { FireEffects }_{i k}\right)\right. \\
& +\beta_{2}\left(\text { CostFactors }_{i k}\right) \\
& +\beta_{3}\left(\text { SiteCharacterisitcs }_{j k}\right) \\
& +\beta_{4}\left(\text { Demographics }_{i}\right)
\end{aligned}
$$

for the $i$ th individual, $j$ th scenario, and $k$ th site.

To calculate travel cost, we combined gas cost plus a fraction of the wage rate to value travel time, an approach conventionally used by US Federal agencies (US Water Resources Council, 1983). By combining the two, consumer surplus does not exhibit omitted variable bias. Because recreation is a time intensive activity, and most workers have fixed 40-h work weeks, total time budget was included as a separate variable in the demand function. The total time budget available for respondents during the summer months was based on weeks of paid vacation and weekend days or whether respondents were retired. Income was also included in the demand specification as reported by respondents. Thus, our demand model implies that visitors maximize utility subject to income and time constraints.

To model the effect of substitution between sites, we calculated distances from each respondent's zip code to the zip code at each potential site to model a proxy price. Therefore, we calculated a unique distance for each respondent zip/site zip combination. Finally, because we sampled onsite, there was the risk of truncation and endogenous stratification. We used an approach developed by Englin and Shonkwiler (1995) to correct for these problems, whereby we subtracted one from the number of trips taken and omitted observations with negative visitation as a result. This was important because by sampling onsite, non-users are not included and the likelihood of sampling individuals depends on the frequency of their visits. Because both have implications for making inferences about individuals in the larger population it was important to correct for this.

\subsection{Travel cost model}

The travel cost demand model is specified to indicate whether fire effects have an influence on the demand for, and value of recreation, and how this may differ between mountain bikers and hikers as specified by the full model in Eq. (4).

$$
\begin{aligned}
\text { TRIPS }= & \beta_{0}+\beta_{1}(\mathrm{AGE})+\beta_{2}(\mathrm{ACRES})+\beta_{3}(\mathrm{BURNOBS}) \\
& +\beta_{4}(\mathrm{BIKE})+\beta_{5}(\mathrm{BIKECROWN}) \\
& +\beta_{6}(\mathrm{BIKECROWNFI} \pm \mathrm{REAGE}) \\
& +\beta_{7}(\mathrm{BIKEFIREAGE})+\beta_{8}(\mathrm{BIKETCCROWN}) \\
& +\beta_{9}(\mathrm{BIKETCFIREAGE}) \\
& +\beta_{10}(\mathrm{BIKETCCROWNFIREAGE})
\end{aligned}
$$

$$
\begin{aligned}
& +\beta_{11}(\text { BIKETCOST })+\beta_{12}(\text { CROWN }) \\
& +\beta_{13}(\text { CROWNFIREAGE })+\beta_{14}(\text { ELEVATION }) \\
& +\beta_{15}(\text { FIREAGE })+\beta_{16}(\text { GENDER }) \\
& +\beta_{17}(\text { GROUPSIZE })+\beta_{18}(\text { HYPAC }) \\
& +\beta_{19}(\text { INCOME })+\beta_{20}(\text { TCCROWN }) \\
& +\beta_{21}(\text { TCFIREAGE })+\beta_{22}(\text { TCOST }) \\
& +\beta_{23}(\text { TCCROWNFIREAGE })+\beta_{24}(\text { TTBUD }) \\
& +\beta_{25}(\text { PROXDIST })
\end{aligned}
$$

The variables in Table 1 used to test contingent effects include CROWN, FIREAGE and interaction terms with these variables. For example, to test the effect of a crown fire on visitation, we set the dummy variable CROWN to 1 (one) for the panel representing visitation in response to a high intensity, two-year-old crown fire. If this variable is significant, it suggests that crown fires affect demand. Similarly, because areas recover from fire effects over time, FIREAGE indicates how people behave in response to areas burned in previous years. When variables such as CROWN and FIREAGE are combined, we can measure the effects of aging crown fires. Finally, to test the effect of increased costs on visitation, the variable TCOST was adjusted for the panel representing increased travel costs.

Because we used a count data model which, is equivalent to a semi-log demand function, we can estimate consumer surplus by dividing the coefficient of the travel cost into one, $1 /\left(\beta_{\text {TCOST }}\right)$ (Loomis et al., 2001). To calculate the consumer surplus for mountain bikers, we include a coefficient for the interaction term BIKETCOST, which is specified by $1 /\left(\beta_{\mathrm{TCOST}}+\beta_{\mathrm{BIKETCOST}}\right)$.

\subsection{Hypothesis tests}

To test the effects of fire age on consumer surplus per trip we combined travel cost with fire age, TCFIREAGE and for mountain bikers, BIKETCFIREAGE. Specifically, if fire age has an effect on the price slope of the demand curve, the coefficient $\beta_{9}$ will not be equal to zero.

Using $t$-tests, we can test for the significance of the fire effects variables on recreation demand. For hikers' fire effect variables are FIREAGE, CROWN, CROWNFIREAGE, while for mountain bikers, they are BIKECROWN, BIKEFIREAGE, and BIKECROWNFIREAGE. Hypothesis tests are specified as follows:

$$
\begin{aligned}
H_{0} & =\beta_{5}(\text { BIKECROWN })=0, \text { vs. } H_{a} \\
& =\beta_{5}(\text { BIKECROWN }) \neq 0 \\
H_{0} & =\beta_{6}(\text { BIKECROWNFIREAGE })=0 \text {, vs. } H_{a} \\
& =\beta_{6}(\text { BIKECROWNFIREAGE }) \neq 0 \\
H_{0} & =\beta_{7}(\text { BIKEFIREAGE })=0, \text { vs. } H_{a} \\
& =\beta_{7}(\text { BIKEFIREAGE }) \neq 0
\end{aligned}
$$


Table 1

Model variables and descriptions

\begin{tabular}{|c|c|}
\hline Variable & Description \\
\hline TRIPS & $\begin{array}{l}\text { Trips taken by the respondent-dependent } \\
\text { variable. This includes actual trips taken and } \\
\text { stated trips taken for each of the scenarios }\end{array}$ \\
\hline BURNOBS & Percentage of fire observable on trail \\
\hline ACRES & Actual number of acres burned \\
\hline AGE & Respondent's age \\
\hline BIKE & Dummy variable for biking, $1=$ biking \\
\hline BIKECROWN & $\begin{array}{l}\text { Interaction between CROWN fire and biking } \\
\text { to test how crown fire influences biking trips }\end{array}$ \\
\hline BIKECROWNFIREAGE & $\begin{array}{l}\text { Interaction between CROWN, FIREAGE } \\
\text { and BIKE to test how trips differ for } \\
\text { mountain bikers according to CROWN and } \\
\text { FIREAGE }\end{array}$ \\
\hline BIKETCOST & $\begin{array}{l}\text { Interaction variable between total cost, and } \\
\text { the dummy for bike to test the effects of total } \\
\text { cost consumer surplus for mountain bikers }\end{array}$ \\
\hline BIKETCCROWN & $\begin{array}{l}\text { Interaction variable between total cost, } \\
\text { CROWN, and the dummy for bike to test the } \\
\text { effects of total cost and crown fires for } \\
\text { mountain bikers }\end{array}$ \\
\hline BIKETCFIREAGE & $\begin{array}{l}\text { Interaction between total cost, FIREAGE and } \\
\text { BIKE to test whether trip value changes for } \\
\text { mountain bikers with FIREAGE }\end{array}$ \\
\hline BIKETCCROWN & Interaction between BIKE, total cost, \\
\hline FIREAGE & $\begin{array}{l}\text { CROWN, and FIREAGE to test the effect of } \\
\text { aging crown fires on net benefits }\end{array}$ \\
\hline CROWN & Dummy variable, $1=$ crown fire \\
\hline CROWNFIREAGE & Interaction between crown fire and fire age \\
\hline ELEVATION & Trailhead elevation above sea level \\
\hline FIREAGE & $\begin{array}{l}\text { Age of fire-negative values: }-10 \text { is ten } \\
\text { years old, }-20 \text { is a } 20 \text {-year-old fire }\end{array}$ \\
\hline GENDER & $\begin{array}{l}\text { Dummy variable for gender, } 1=\text { male, } \\
0=\text { female }\end{array}$ \\
\hline GROUPSIZE & Number of people in group. \\
\hline HYPAC & $\begin{array}{l}\text { Dummy variable: } 1=\text { hypothetical response } \\
\text { to contingent scenario, } 0=\text { actual trip taken }\end{array}$ \\
\hline INCOME & $\begin{array}{l}\text { Annual household income of survey } \\
\text { respondent }(\$ 000)\end{array}$ \\
\hline TCOST & $\begin{array}{l}\text { Stated travel cost per individual plus travel } \\
\text { time to site (h) valued at } 33 \% \text { of wage } \\
\text { calculated as annual income divided by } 2000\end{array}$ \\
\hline TCCROWN & $\begin{array}{l}\text { Interaction variable between total cost and } \\
\text { crown to test the effects of crown fires on } \\
\text { consumer surplus }\end{array}$ \\
\hline TCFIREAGE & $\begin{array}{l}\text { Interaction between travel cost and fire age to } \\
\text { test whether value per trip changes with fire } \\
\text { age }\end{array}$ \\
\hline TCCROWNFIREAGE & $\begin{array}{l}\text { Interaction between travel cost, crown fire, } \\
\text { and fire age to determine the effect of aging } \\
\text { crown fires on net benefits }\end{array}$ \\
\hline TTBUD & $\begin{array}{l}\text { Total time budget available for travel is } \\
\text { calculated as annual vacation days and } \\
\text { weekend days. In the case of retired } \\
\text { respondents } 180 \text { days was used for the total } \\
\text { trip budget }\end{array}$ \\
\hline PROXDIST & $\begin{array}{l}\text { Summation of the distances from each } \\
\text { respondent's origin to each site used as a } \\
\text { proxy for substitute price }\end{array}$ \\
\hline
\end{tabular}

$$
\begin{aligned}
H_{0} & =\beta_{12}(\mathrm{CROWN})=0, \text { vs. } H_{a}=\beta_{12}(\mathrm{CROWN}) \\
& \neq 0 \\
H_{0} & =\beta_{13}(\mathrm{CROWNFIREAGE})=0, \text { vs. } H_{a} \\
& =\beta_{13}(\mathrm{CROWNFIREAGE}) \neq 0 \\
H_{0} & =\beta_{15}(\text { FIREAGE })=0, \text { vs. } H_{a}=\beta_{15}(\text { FIREAGE }) \\
& \neq 0
\end{aligned}
$$

We use regression results to estimate the effects of fire on value per day (individual consumer surplus), and the individual number of trips taken.

\section{Data collection}

\subsection{Sample design, survey protocol and structure}

Ten sites on five national forests in New Mexico were selected for this study based on recreation use and fire history. Because there were few trails that had burned in the last 50 years, we had eight control sites, and two sites that had been burned. One site included a 50-year old fire of 22,000 acres which was a mixed-severity burn. The other site burned in the year 2000, was 20,000 acres, but was not a crown fire. Sites sampled that were not affected by fire recently were coded for fire age as 50 years old.

Two sites were surveyed on the Santa Fe National Forest, approximately 80 miles North of Albuquerque with an elevation of 7500 feet. The main vegetation types were ponderosa pine, scrub oak and juniper. These sites included areas that are heavily overgrown with dense underbrush of vines, shrubs and other deciduous trees. The two Jemez sites included a 25-year-old crown fire, a five-year-old crown fire, and a one-year-old crown fire.

The Sandia site on the Cibola National Forest is situated at the Sandia Crest Observation Point approximately 50 miles from Albuquerque and is accessible via trails, tram, and road with an elevation of 10,680 feet. The site includes small springs and streams many of which are seasonal. The Sandia Crest Observation area has a three-tiered parking lot that serves approximately seven trails, the road to the top, and the lookout. There were no recorded fires in the Sandias so fire age was recorded as 50 years old.

The Ruidoso site is situated in the Lincoln National Forest at approximately 8000 feet in Southern New Mexico. The vegetation is primarily ponderosa pine, but spruce-fir and Engleman spruce are present at higher altitudes. The Lincoln National Forest has had significant fire in the past 25 years, however, most of the effects have occurred in wilderness areas where there are no trails or developed recreation sites.

Cedro is located in the Sandia Ranger District in the Cibola National Forest approximately 30 miles from 
Albuquerque on the southeastern side of the Sandias. It is primarily a mountain biking and ATV recreation site. It has several trails that start at approximately 7,000 feet with an elevation gain of 1500 feet at Cedro Peak. Juniper is located at the lower elevations and gradually gives way to meadows and some ponderosa pine as the trails near Cedro Peak. There is visible fire damage from a 10-year old fire, although the trail does not go through the burned area. La Luz, also in the Sandias foothills, is the most heavily used trail in the New Mexico system beginning at 8000 feet and rising to 10,680. The lower La Luz is characterized by numerous cacti and rocks and gradually gives way to ponderosa pine and spruce-fir with elevation gain. Finally, Tree Spring, located on the backside of the Sandia Mountains climbs from 8500 feet to 10,700 feet. The predominant vegetation is spruce-fir and the area is designated as multi-use. Tree Spring is one of the few trails in the Sandia Wilderness area that allows mountain bikes, however, no mountain bikers were observed at this site. There is no fire history at this site.

We also surveyed a site entering the Gila Wilderness Area which includes the Gila Cliff Dwellings run by the National Park Service. The parking lot, restroom facilities and the trails/campground are all run by the Forest Service. The Gila Cliff Dwellings National Monument is 45 miles away from Silver City, in Southern New Mexico. The main vegetation is ponderosa pine and cottonwood at the trailhead, and spruce with gains in elevation. At the highest points on the trails, there are Engleman Spruce. The Gila has a significant burn history. There is visible fire damage with scorched trunks, although there are very few dead trees and substantial regeneration. In many areas, the fire damage is barely noticeable, however the trails that wind throughout the area do have some fire damage visible, as do the camping areas.

Taos sites were located in the Carson National Forest, Quemado Ranger District and include the Wheeler Peak, Bull of the Woods and Williams Lake Trails. The elevation is over 9000 feet at the trailhead and goes up to more than 11,000 feet. The vegetation is Englemen Spruce, fir and some ponderosa pine. All trails cross a permanent stream and go to a high mountain lake (Williams Lake).

To augment the natural variation in fire ages and burn intensities, it was useful to ask users to respond to other fire regime scenarios to better understand how their visitation would be affected by prescribed burning and recent crown fires. Therefore, we also included a contingent visitation behavior question based on photos that depicted half of each trail as severely burned, moderately burned, and recovering from severe burn. Contingent visitation behavior was based on three fire scenarios using color photographs of the following:

- High-intensity crown fire: the fire was two years old, with blackened, standing trees and very little greenery.
- Light prescribed burn: two years old, the underbrush was burned, trees were burned on the lower portions of the trunks, and reddish needles were showing on lower branches, whereas green needles were showing in the crowns.

- High-intensity 20-year old burn: the photo indicated standing dead trees with white trunks, and a mix of downed trees, with new green young trees.

Respondents were asked how their visitation to each site would change if $50 \%$ of the trail they were on resembled the photo. This enabled us to efficiently convey the effects that high-intensity crown fires, prescribed fires, and older burns have on recreation demand. Because financial limitations, we were unable to make 'percentage of trail affected' a variable.

Sites were sampled throughout the summer months of 2001. Sampling was conducted on both weekdays and weekends. The interviewer intercepted individuals at each trailhead, introduced herself, and gave her university affiliation and purpose. Respondents were told they could complete the survey on site, or take it home and mail it back in a postage-paid, return envelope. Surveys were disseminated to individuals 18 years or older. Respondents were asked to list their primary recreation activity and attributes of the site that were important to them. They also recorded travel time, travel distance, and travel cost to the site. Travel cost included gas cost, camping fees and other travel-related expenditures. Individuals recorded the number of trips taken to the site for the survey year and the year prior. We asked how visitation might change if the cost of the trip had increased holding fire and non-fire characteristics constant for the trail on which they were intercepted. These stated preference data were collected based on price using increased trip costs of $\$ 3,7,9,12,15,19,25,30,35,40$, and 70. This provided additional price variability to supplement the natural variability in travel costs due to different originations.

We also included site characteristics to control for variability among trails. Attributes were chosen based on those that were significant in past forest recreation studies (Englin et al., 1996; Loomis et al., 2001). Fire history information included fire age, size of burn, and intensity. Because we sampled areas that were affected by fires, we collected actual fire data which was verified with the USDA Forest Service.

Revealed preference and stated preference data were combined in six panels. To distinguish between revealed and stated preference, we created a dummy variable, HYPAC (hypothetical vs. actual). Actual trips taken for 2000 and 2001 were recorded as HYPAC $=0$. For the four contingent behavior scenarios (high intensity crown fire, low intensity prescribed burn, old high intensity fire, increased trip cost), this variable was coded as HYPAC $=1$. Individual observations were stacked into six panels thereby giving us six observations for each 
respondent. The first and second panels represented actual trips taken. Site data and fire characteristics were recorded in these two panels as actual observations and actual fire history. Panels three through five represented, for each individual, stated preference responses relating to each of the three fire scenarios presented in the photographs. While non-fire site characteristics remained the same, fire history was coded according to fire characteristics relating to each of the three scenarios depicted by the photos. For each scenario, the percentage burn observable from the trail was recorded as $50 \%$. Finally, the sixth panel included contingent behavior based on increased travel costs. In this panel, actual fire history and site characteristics were used.

\section{Results}

The total number of contacts made was 1302 . The overall response rate was $30 \%$ with 392 surveys returned after first and second postcard reminders were mailed to those who provided mailing information. Overall, 203 individuals refused to provide address information for postcards possibly contributing to a lower response rate. Once data were adjusted for multiple visits and completeness, 379 observations were used for the analysis. A description of the travel information, visitation, respondent characteristics and visitation is given in Table 2 .

Table 2

Descriptive statistics

\section{Travel}

Average travel time to site (h)

Average travel distance (mi)

Average gas cost (\$)

Visitation

Hours spent onsite (h)

Miles traveled onsite (mi)

Respondent characteristics Group size (pers.)

Male (\%)

Retired (\%)

Average age (years)

Education (years)

Employed (\%)

Household size (pers.)

Average income (\$)

Trips taken actual (per person)

Current year

Previous year

Trips taken hypothetical (per person)

High intensity 2-year old fire

Low intensity 2-year old fire

High intensity 20-year old fire

Increased cost scenario
Visitors traveled an average of $3.3 \mathrm{~h}$ and 231 miles to recreation sites with an average gas cost of \$27. Groups stayed an average of $10.2 \mathrm{~h}$ on site and covered an average of 10.4 miles. Average group size was 4.3 individuals. The sample population was $49.6 \%$ male, 45.6 years old and on average had baccalaureate degrees. Retired persons make up $19.5 \%$ of the sample, whereas $74 \%$ reported they were employed. Household size was 2.4 people and average income was $\$ 74,000$.

Raw data indicated that mean visitation per person per year was 2.11 in the year prior to the survey and 3.29 trips in the year of the survey. With respect to the hypothetical scenarios, stated preference decreased to 1.96 trips per person per year for the high-intensity fire, 3.08 for the twoyear old low intensity prescribed fire, and 2.03 trips for the 20 -year old high intensity fire. When we increased the cost of travel, mean trips fell to 1.88 .

Results of the Poisson recreation demand model are displayed in Table 3. Based on the likelihood ratio statistic,

Table 3

Travel cost recreation demand model results: hikers and mountain bikers

\begin{tabular}{|c|c|c|c|}
\hline \multicolumn{4}{|l|}{ Variable } \\
\hline & Coefficient & Std Err. & $P$-value \\
\hline \multicolumn{4}{|l|}{ Demand slope and intercept } \\
\hline Constant & 3.0041 & 0.1992 & 0.000 \\
\hline Bike & 1.2122 & 0.0950 & 0.000 \\
\hline TCOST & -0.0077 & $7.31 \times 10^{-04}$ & 0.000 \\
\hline Bike $\times$ TCOST & 0.0010 & 0.0012 & 0.418 \\
\hline \multicolumn{4}{|c|}{ Travel cost and fire and activity interactions } \\
\hline TCCROWN & -0.0034 & $2.21 \times 10^{-03}$ & 0.124 \\
\hline TCFIREAGE & 0.0003 & $4.39 \times 10^{-05}$ & 0.000 \\
\hline TCCROWNFIREAGE & $-4.40 \times 10^{-05}$ & $8.81 \times 10^{-05}$ & 0.617 \\
\hline BIKETCCROWN & -0.0935 & 0.0169 & 0.000 \\
\hline BIKETCFIREAGE & 0.0005 & 0.0001 & 0.000 \\
\hline BIKETCCROWNFIREAGE & 0.0009 & 0.0002 & 0.000 \\
\hline \multicolumn{4}{|l|}{ Fire effects } \\
\hline CROWN & -0.2415 & 0.0824 & 0.003 \\
\hline CROWNFIREAGE & -0.0200 & $5.87 \times 10^{-03}$ & 0.000 \\
\hline FIREAGE & 0.0113 & 0.0025 & 0.000 \\
\hline BIKECROWN & 0.1882 & 0.1574 & 0.231 \\
\hline BIKEFIREAGE & -0.0050 & 0.0021 & 0.019 \\
\hline BIKECROWNFIREAGE & -0.0302 & 0.0096 & 0.001 \\
\hline BURNOBS & -0.0158 & 0.0026 & 0.000 \\
\hline ACRES & $-4.90 \times 10^{-05}$ & 0.0026 & 0.000 \\
\hline \multicolumn{4}{|l|}{ Demographic variables } \\
\hline AGE & -0.0135 & 0.0016 & 0.000 \\
\hline GENDER & 0.0591 & 0.0361 & 0.101 \\
\hline GROUPSIZE & -0.0982 & 0.0095 & 0.000 \\
\hline TTBUD & -0.0011 & 0.0006 & 0.059 \\
\hline INCOME & $8.69 \times 10^{-09}$ & $4.78 \times 10^{-07}$ & 0.985 \\
\hline HYPAC & $2.27 \times 10^{-01}$ & $5.58 \times 10^{-02}$ & 0.000 \\
\hline$R$-squared & 0.371 & & \\
\hline Adjusted $R$-squared & 0.358 & & \\
\hline Probability (LR stat) & 0.000 & & \\
\hline
\end{tabular}


the model is significant at $p<0.01$ and has an adjusted $R$ squared of 0.35 . There is a statistically significant difference between trips taken by hikers and mountain bikers indicating that the number of trips taken by mountain bikers is significantly greater. The mean number of trips taken by hikers is 1.17 , whereas the mean number of trips taken by mountain bikers is 1.58 .

Travel cost, which includes the value of travel time, is significant and negative at $p<0.01$. However, there is no statistically significant difference between travel cost for mountain bikers and hikers. The HYPAC variable is positive and significant indicating that respondents overstated the intended number of trips taken under the hypothetical scenarios. For example, the mean number of trips with HYPAC $=1$ was 1.98 for bikers and 1.47 for hikers. To correct for overstatement, trip demand and value estimates were made using $\mathrm{HYPAC}=0$.

With respect to substitution, cross price terms used to measure substitution were nearly perfectly correlated which was expected given that the farther the respondent lived from one site, the farther they lived from all others. Similarly, the variable PROXDIST was omitted from the final model because it caused travel cost to be insignificant, and resulted in a negative value indicating complementary relationship rather than that of substitutes.

Significant demographic variables include group size (GROUPSIZE) $(p<0.00)$, total time budget (TTBUD) $(p<0.059)$, and respondent's age (AGE) $(p<0.01)$, each of which were negative.

\subsection{Consumer surplus}

Net benefits or consumer surplus is calculated from the travel cost and travel cost related coefficients in Table 3 as one divided by the coefficient on travel cost. As shown in Table 4, consumer surplus for hikers was $\$ 130$ with a $95 \%$ confidence interval of $\$ 110$ to $\$ 160$. Consumer surplus for mountain bikers was $\$ 151$, which was not statistically significantly different from that of hiking. The values for hiking are consistent with a recent study by Loomis et al. (2001) who determined consumer surplus to be $\$ 111$ when travel cost was combined with travel time. Similarly, Casey et al. (1995) determined individual values for hiking to be \$218.37. Finally, Englin et al. (2001) calculated consumer surplus for hiking to be \$222 in Wyoming, \$129 in Idaho, and $\$ 109$ in Colorado. With respect to biking, the only values available were calculated by Loomis et al. (2001) to be between $\$ 30$ and $\$ 33$. For more information regarding consumer surplus estimates see Rosenberger and Loomis (2001).

Net benefits were also affected by crown fires (CROWN), time since crown fire (CROWNFIREAGE), and time since prescribed fire (FIREAGE). The interaction variable between travel cost and crown (TCCROWN) fire resulted in a significant decrease in consumer surplus for mountain bikers dropping from $\$ 151$ to $\$ 10$ (Table 4). Similarly, hikers experienced a decrease in value from $\$ 130$ to $\$ 90$.

Using illustrative values of 20 and 40 years as examples we calculated the price and demand effects over time. As areas recover from prescribed fire, both hikers and mountain bikers experience a decrease in annual values (Table 4). Similarly, trips taken also decrease for both hikers and bikers. For hikers, trips range from 1.93 in year zero to 0.60 forty years after a fire, and net benefits per trip decrease from $\$ 130$ to $\$ 52$. The annual effect is a decrease from $\$ 252$ to $\$ 31$ over a period of 40 years. For mountain bikers, the number of trips taken also decreases over a 40 -year period from 6.91 to 0.73 , while net benefits per trip decrease dramatically, dropping from $\$ 151$ to $\$ 26$ (Table 4). All coefficients were significant at $p<0.01$.

Recovery from crown fires affect value differently for hikers and mountain bikers: hikers experience an increase in value per trip with recovery whereas mountain bikers experience a decrease as areas recover from crown fires. Over a 40-year period the number of trips taken by hikers decreases from 1.24 to 0.95 . Net value however, increases from $\$ 90$ to $\$ 107$ resulting in a decrease in annual benefits

Table 4

Trips and annual recreation values as a function of years after fire

\begin{tabular}{|c|c|c|c|c|c|c|c|}
\hline & \multirow[t]{2}{*}{ Mean } & \multicolumn{3}{|c|}{ Prescribed fire } & \multicolumn{3}{|c|}{ Crown fire } \\
\hline & & 0 years & 20 years & 40 years & 0 years & 20 years & 40 years \\
\hline \multicolumn{8}{|l|}{ Hikers } \\
\hline Trips & 2.8 & 1.93 & 1.08 & 0.60 & 1.24 & 1.09 & 0.95 \\
\hline Value PER TRIP & & $\$ 130.24$ & $\$ 74.19$ & $\$ 51.87$ & $\$ 90.29$ & $\$ 98.09$ & $\$ 107.35$ \\
\hline Annual value & & $\$ 251.89$ & $\$ 79.77$ & $\$ 31.01$ & $\$ 112.21$ & $\$ 106.49$ & $\$ 101.83$ \\
\hline \multicolumn{8}{|l|}{ Mountain bikers } \\
\hline Trips & 6.2 & 6.91 & 2.24 & 0.73 & 0.02 & 0.01 & 0.00 \\
\hline Value PER TRIP & & $\$ 150.53$ & $\$ 44.05$ & $\$ 25.80$ & $\$ 9.66$ & $\$ 8.24$ & $\$ 7.19$ \\
\hline Annual value & & $\$ 1040.20$ & $\$ 98.78$ & $\$ 18.78$ & $\$ 0.15$ & $\$ 0.07$ & $\$ 0.03$ \\
\hline
\end{tabular}


from $\$ 112$ to $\$ 101$ (Table 4). Trips taken by mountain bikers decrease from 0.02 to 0.00 . Similarly, net value decreases from $\$ 10$ to $\$ 7$ resulting in a decrease in annual benefits from $\$ 0.15$ to $\$ 0.03$. The hikers' and mountain bikers' demands are consistent with the existing literature (Vaux et al., 1984; Loomis et al., 2001). All coefficients pertaining to crown fires were significant at $p<0.01$ with the exception of the value of aging crown fires for bikers.

\subsection{Fire effects}

Significant fire effects include the percentage of burn observable from the trail, presence of crown fire, aging crown fires, and prescribed fires. Although we did not vary burn percentage in the survey (for each scenario respondents assumed $50 \%$ of the trail had been burned), site characteristics varied by the actual percentage of burn visible for each trail. The coefficient of \% BURNOBS indicated that as percentage burned increased, mean visitation decreased. For hikers, mean trips are 1.92 for no burns, 1.10 trips for $35 \%$ burn observable, and 0.50 for $85 \%$ burn observable. Bikers also experience a decrease in visitation for increasing burn observable; over the same range trips begin at 2.07 and decrease to 1.19 and 0.54 .

The presence of a crown fire onsite increased the number of trips for hikers from a mean of 1.17 to 1.24 and decreased the number of trips for mountain bikers from a mean of 2.03 to 0.02 (Table 4). However, there were no significant differences of crown fire effects between hikers and mountain bikers. Aging prescribed fires was also significant and affected hikers and mountain bikers to different degrees. Over a 40-year period, hikers decreased visitation from 1.93 to 0.60 as did mountain bikers from 6.91 to 0.73 (Table 4).

We interacted crown fire with fire age to determine the effects of crown fires on visitation as areas recovered from fire. This variable was significant at $p<0.01$. For areas without fires, the average number of trips taken by hikers was 1.24. As crown fires increased in age to 20 and 40 years, the number of trips taken decreased to 1.09 and 0.95 per individual (Table 4). Similarly, for the same fire age range, mountain bikers' demand dropped effectively to zero $(0.02$, 0.01 , and 0.00). There was a significant difference in the effects of aging crown fires between the two activities indicated by $p<0.01$.

These results can be compared to those of Loomis et al. (2001) who investigate hiking and biking in Colorado, and Englin et al. (2001) who examine hiking demand in Wyoming, Idaho and Colorado. With respect to fire effects over time, Englin et al. found an initial increase in visitation for all states, followed by a 17 -year decline in visitation, an eight-year rebound, and another sharp decline over two years. Loomis et al. show only a slight decline in visitation for hikers in areas recovering from crown fires. Visitation for hikers and bikers in recovering prescribed burns demonstrate increased visitation over 50 years.

\section{Conclusion}

Although there was a significant difference between the extent to which hikers and mountain bikers reacted to crown fire, the effects were similar for prescribed fire. In the case of prescribed fires, the number of trips taken decreases over time for recreationists engaged in both activities and the value per trip decreases for both activities although more dramatically for mountain bikers. With respect to crown fires, visitation to areas recovering from crown fires decreases for both activities, yet consumer surplus per trip does not change similarly; the value per trip for mountain bikers decreases over time whereas the net value for hikers increases over time. With respect to fire effects, both hikers and mountain bikers reacted similarly to recovering prescribed fires, and recovering crown fires. In each case, visitation decreased. The combined effects of visitation and consumer surplus indicated decreases in annual values which, is not consistent with Loomis et al. (2001) indicating that there are important geographic variations in behavior. First, hikers and mountain bikers in New Mexico react more similarly than do hikers and mountain bikers in Colorado. The Colorado results show that for areas recovering from prescribed fires annual values for hikers increase slightly whereas annual values for mountain bikers decrease slightly. For areas recovering from crown fires, the Colorado results are reversed with annual hiker values falling but mountain biker values increasing with recovery from crown fires. New Mexico results suggest that annual values for both hikers and mountain bikers decrease for areas recovering from prescribed fires and only hikers show an increase in per trip values over time in response to areas recovering from crown fire.

These results are important for two reasons. They show that groups engaged in different recreation activities do not always behave similarly in response to different levels of fire intensity, a result also found in Colorado. This suggests that fire managers should consider the types of trail users when deciding which fuels management techniques to employ. Both hikers and mountain bikers in New Mexico exhibit decreased annual values in response to prescribed fire, which suggests that perhaps other types of fuels treatments (mechanical for example) may be more socially acceptable, and ultimately less costly. However, a revealed and stated preference survey showing alternative fuel treatments would be necessary before this can be confirmed. Similarly, although we surveyed only recreation visitation and value, we did not question respondents about ecological values associated with prescribed burning or wildfires. It may be the case that recreation consumers are willing to forego visitation in lieu of ecological restoration or improvement. While these issues are beyond the scope of this research, tradeoffs between ecological integrity and recreation use would be a interesting and important issue to analyze. 
The second important finding is that recreation users in different states do not behavior similarly. For example, hikers in New Mexico indicated decreased value over time to areas recovering from prescribed fire whereas hikers in Colorado exhibited increased value over time. This finding has implications for the national fire policy suggesting that not all recreation users can be treated similarly. The National Fire Plan calls for an increase in the use of prescribed fire to reduce hazardous fuels levels. Whereas prescribed fire may be an efficient and effective solution to hazardous fuels reduction from an ecological perspective, it may not be socially desirable in all regions. For example, while prescribed fire in Colorado slightly increases annual hiking values over time, it decreases annual net benefits to mountain bikers in New Mexico. This suggests that fire managers must pay attention to regional social differences when determining the best fuels management techniques to employ. These findings are important too for forests and recreation sites in temperate areas such as Europe. While fire has the potential to influence value and visitation, the resultant costs and benefits of management may not be socially efficient nor ecologically effective when compared with policies to let forests burn without intervention. Likely, the suite of costs, benefits and risks in different temperate zones will vary according to sites and user activities. To assess such impacts, and to compare recreation value and visitation across political and ecological boundaries, it would be useful to conduct similar surveys. Finally, a word of caution. Although this research generates specific values for hiking and biking, because it is site specific due to demographic differences, these values may not be applicable in other regions.

\section{Acknowledgements}

Funding for this survey was provided by the Joint Fire Sciences Program.

\section{Appendix A}

\section{Contingent scenarios and contingent behavior questions}

Each of the three scenarios depicted by the photographs were presented with the following narrative.

"The picture below displays what a portion of this trail would be like if it had been burned by a recent forest fire. Please take a few moments to look at the photo below.

Suppose that at the beginning of the season you read that $50 \%$ of the area along this trail would have been burned by a forest fire such as shown in the photo above.

Would this have affected the number of trips you would take to this area each month?
Please write down what your trips would have been or you would have taken to this area if it had been burned as shown in the photo for half the trail you visited

\begin{tabular}{llllll}
\hline & May & June & July & Aug. & Sept. \\
$\begin{array}{l}\text { Trips you } \\
\text { would take }\end{array}$ & & - & - & - & - \\
\hline
\end{tabular}

Any comments on your answer to this question?"

Similarly, question 15 was presented to obtain stated preference data regarding hypothetical travel costs. Costs were randomly varied among sites and respondents $(\$ 3,7$, $9,12,15,19,25,30,35,40$, and 70).

15. The cost of recreation changes with gas prices and equipment costs. If the cost of visiting this site had been $\$$ per trip higher tell us how many trips you would take in each month?

\begin{tabular}{llllll}
\hline & May & June & July & Aug. & Sept. \\
$\begin{array}{l}\text { Trips you } \\
\text { would take }\end{array}$ & & - & - & - & - \\
\hline
\end{tabular}

\section{References}

Boxall, P., Watson, D., Englin, J., 1996. Backcountry recreationists' valuation of forest and park management features in the Canadian Shield Region. Canadian Journal of Forest Research 26, 982-990.

Casey, J.F., Vukina, T., Danielson, L.E., 1995. The economic value of hiking: further considerations of opportunity cost of time in recreational demand models. Journal of Agricultural and Applied Economics 27, $658-668$.

Englin, J., Cameron, T.A., 1996. Augmenting travel cost models with contingent behavior data. Environmental Research Economy 7, $133-147$.

Englin, J., Shonkwiler, J.S., 1995. Estimating social welfare using count data models: an application to long-run recreation demand under conditions of endogenous stratification and truncation. Reviews in Economy and Statistics 77 (1), 104-112.

Englin, J., Boxall, P., Chakraborty, K., Watson, K., 1996. Valuing the impacts of forest fires on backcountry forest recreation. Forest Science $42,450-455$.

Englin, J., Loomis, J., González-Cabán, A., 2001. The dynamic path of recreational values following a forest fire: a comparative analysis of states in the Intermountain West. Canadian Journal of Forest Research 31, 1837-1844.

Laverty, L., Hartzell, T., 2001. USDA Forest Service and Department of the Interior. 2000. A Report to the President In Response to the Wildfires of 2000, September 8, 2000.

Loomis, J., Roach, B., Ward, F., Ready, R., 1995. Testing transferability of recreation demand models across regions. Water Resources Research 31 (30), $721-730$.

Loomis, J.B., Englin, J., González-Cabán, A., 1999. Effects of fire on the economic value of forest recreation in the intermountain west: 
preliminary results. USDA Forest Service Gen-Tech. Rep. PSW-GTR173, pp. 199-208.

Loomis, J.B., González-Cabán, A., Englin, J., 2001. Testing for differential effects of forest fires on hiking and mountain biking demand and benefits. Journal of Agricultural and Resource Economics 26 (2), $508-522$.

Morey, E., 1982. The demand for site specific recreational activities: a characteristics approach. Journal of Environmental Economics and Management 26, 245-271.

Rosenberger, R.S., Loomis, J.B., 2001. Benefit transfer of outdoor recreation use values: a technical document supporting the Forest Service Strategic Plan (2000 revision). Gen. Tech. Rep. RMRS-GTR72. Fort Collins, CO: US Department of Agriculture, Forest Service, Rocky Mountain Research Station. 59 pp.
US Water Resources Council, 1983. Principles and Guidelines for Water and Related Land Implementation Studies, US Water Resources Council, Washington DC.

Vaughan, W., Russell, C., 1982. Valuing a fishing day: an application of a systematic varying parameter model. Land Economics 58 (4), $450-463$

Vaux, H.J., Jr., Gardner, P.D., Mills, T.J., 1984. Methods for assessing the impact of fire on forest recreation. Pacific Southwest Forest and Range Experiment Station, USDA Forest Service. GTR-PSW-79.

Ward, F., Beal, D., 2000. Valuing Nature with Travel Cost Models, Edward Elgar, Northhampton, MA.

Ward, F., Roach, B., Henderson, J., 1996. The economic value of water in recreation. Water Resources Research 32 (4), 1075-1081. 